CURRENT RESEARCH JOURNAL OF PEDAGOGICS 2(12): 119-123,

December 2021 DOI: https://doi.org/10.37547/pedagogics-crjp-02-12-24

ISSN 2767-3278

(C)2021 Master Journals

Crossref dof 81 Google

Accepted $18^{\text {th }}$ December, 2021 \& Published 23 th December, 2021

\title{
THEORETICAL FUNDAMENTALS OF MUSIC EDUCATION METHODOLOGY
}

Nafisa Jaxbaralievna Arslanova

Master, Namangan State University, Uzbekistan

Kizlarhon Anvarovna Isamova

Master, Namangan State University, Uzbekistan

\section{ABSTRACT}

Any science consists of a conclusion, a summary, a system of reliable and generalized knowledge about the objective laws of nature, society and the development of thought. The existence of a special understanding is an indispensable condition for the separation and normative activity of any science. Upbringing, education and teaching are the basic concepts of pedagogy as a science.

KEYWORDS: - Upbringing, education, teaching, aesthetics, music, listening, performance.

\section{INTRODUCTION}

Upbringing is a type of social relationship in which the same category of people influence others in order to form a person in a focused way.Education is an aspect of education that includes a system of scientific and cultural values accumulated by mankind. Education is obtained in different ways.

Teaching is a process of mastering certain aspects of the socio-historical experience of mankind by students under the guidance of a specially trained person (teacher, educator, professor, instructor), a process that integrates the educational, pedagogical and developmental functions.[1]

The methodology of music education enters the system of pedagogical sciences and occupies a special place in it. Issues of music education in modern pedagogy are considered in connection with the general problems of education. Musicalaesthetic education is a much broader concept than music education. In this process, music lessons play an important role, but do not play a special role. Active role in music education is played by the active development of musical comprehension skills, the formation of a sense of love for art and the beautiful things in life, as well as the ability to creatively express their feelings in the language of music. If we talk about music education in a broad pedagogical sense, it means 
CURRENT RESEARCH JOURNAL OF PEDAGOGICS 2(12): 119-123,

December 2021 DOI: https://doi.org/10.37547/pedagogics-crjp-02-12-24

ISSN 2767-3278

(C)2021 Master Journals

Crossref dof 81 Google

Accepted $18^{\text {th }}$ December, 2021 \& Published 23 th December, 2021

that the whole educational process in the system of educational institutions is organized in accordance with a specific purpose. The purpose of a purposeful, well-organized musical education is to form a well-rounded and harmoniously developed person who is always ready to work and social activity and to love the motherland.

Active perception of beauty in music requires thinking. In the creation and perception of music, one should never refuse to make an intellectual decision. When we listen to music, we not only feel or experience certain situations, but we also distinguish, select, evaluate, and think about the material being perceived.

The development of musical perception and taste, the development of musical abilities are always intertwined with mental and moral education. Musical perception encompasses more than the perception of beauty, and the perception of beauty, in turn, is one of the types of musical perception. It is possible to perceive all the beautiful things in music, but not everything that is perceived in music is beautiful.[2]

In beauty, the positive aspects of reality are reflected. When we are in different moods in our musical perception of life events and happenings, and when we perceive beauty, we only enjoy it.

Also, having a real musical taste is one of the important qualities of this person. Because in the taste the spiritual world of this or that person is revealed. So, the struggle for a healthy taste means caring for the human nature of the person. A student with a perfect musical taste is not only a student who understands the masterpieces of art, he will appreciate the beauty of life in any form - in nature, manners, work or things around him. He is ready to strike at all ideological and moral depravity.

The role of literature and art in educating students in the aesthetic spirit, in developing their artistic taste is enormous. Because the art of music has a great potential in the formation of moral values in children, in the development of such qualities as an active attitude to life. Art not only instills in students a high sense of humanity, but also has a positive effect on their spiritual growth.

Modern music lessons, in addition to the specific tasks of musical nature and education, should also set themselves the following tasks. The system of music education at school consists of many elements: music lessons, music education outside the classroom and school, vocal and choir studios and clubs, vocal and instrumental ensembles, music schools, etc. The media plays a very important role in this system. All educational and developmental tools create a musical and aesthetic environment in which students' interests and needs in the field of music. Music lessons at school are part of the system of aesthetic education, which in many respects is aimed at the spiritual development of students. The development and enrichment of musical and creative abilities, the formation of musical comprehension skills, an interest in the art of music, the artistic hobby of students should be carried out in a well-thought-out and consistent system.[3]

Music lessons are distinguished by specific types of activities: listening and analyzing a piece of music, singing, performing under the music, creating music. In the course of the lesson, these types of activities can not be separated from each other, because they are interconnected and sometimes intertwined. In the process of listening to music, students gain a certain amount of musical-theoretical knowledge, gain experience in the ability to listen to music, and at the same time develop analytical skills. Singing as a group develops all the components of the singing voice and the ability to listen to music (high volume, rhythm, harmony of sounds, 
CURRENT RESEARCH JOURNAL OF PEDAGOGICS 2(12): 119-123,

December 2021 DOI: https://doi.org/10.37547/pedagogics-crjp-02-12-24

ISSN 2767-3278

(C)2021 Master Journals

Crossref dof 81 Google

Accepted $18^{\text {th }}$ December, 2021 \& Published 23 th December, 2021

timbre). The development of performance skills in the process of singing in a choir, children's playing musical instruments, moving under the music improvisation (free creation) makes students active, interested, emotional participants in the learning process.

The task of music science is to teach children to be active in beauty, to be creative in music. This can be achieved not only on the basis of mastering and understanding any work, but also on the basis of knowledge of the history of its creation, the basics of music theory, the laws of its development.[4]

However, the understanding of music is the basis for all types of student activities in the classroom. Understanding music is necessary for a full understanding of life around you, because ultimately the ability to delve into the essence of the work of art and the aesthetic thing in life contributes to the full development of the student's personality. Music lessons, like all subjects, must solve the tasks they set for themselves, and the more actively and purposefully they solve these tasks, the higher the level of music education for schoolchildren. The lesson is an organizational form of school work in which the teacher works with a permanent group of students in a clearly defined time-class according to a strict schedule, leading the team's learning activities and entering the curriculum. uses a variety of methods to achieve the didactic and educational tasks that it determines.

The teaching process can be considered as a goal-oriented, coherent and interrelated activity of teachers. During this activity, the tasks of education, development and upbringing of the participants are solved.

The process of interaction between the student and the teacher in music lessons is based on personal contact. The work of the teacher in the classroom creates the basis for all students to acquire the basics of knowledge, skills and abilities acquired in the classroom.

Each music lesson should enrich students with new knowledge, expand their horizons, develop their musical skills and abilities, or improve what they have already learned. As students step by step from class to class, they move up the endless ladder of knowledge. Music lessons provide comprehensive development of students in the field of music, create the basis for their musical culture.

Music lessons give a sense of the joy of music, a sense of belonging to beauty, the ability to enjoy the moral and aesthetic content of the work of a composer or folk music. All types of creative activities, which are closely connected with each other, are effective in the classroom.

At the same time, the content, methods and organization of the lesson should have a great educational value, having an educational impact on students, forming in them a scientific worldview, ideological beliefs, spiritual qualities of the individual.

The upbringing, teaching, development and education of students in the classroom should be carried out jointly and in interaction. This is one of the most important principles of music pedagogy.

The school does not aim to prepare students for professional music activities. However, the ability to understand, comprehend and be influenced by music gives each student the basic knowledge, skills and abilities of musical and aesthetic activity in a very diverse form of music culture, whether he will be a professional musician in the future. It should be unique, regardless of whether the deceased will be a well-prepared listener.

Currently, the requirements for music lessons are:

1. Music lessons imply a complex 
CURRENT RESEARCH JOURNAL OF PEDAGOGICS 2(12): 119-123,

December 2021 DOI: https://doi.org/10.37547/pedagogics-crjp-02-12-24

ISSN 2767-3278

(C)2021 Master Journals

Crossref dof 81 Google

Accepted 18 ${ }^{\text {th }}$ December, 2021 \& Published 23 ${ }^{\text {th }}$ December, 2021

implementation of the functions of education, development and upbringing. Influences all aspects of the formation of the student: along with increasing the musical knowledge of the student, develops mental strength and abilities, forms the worldview, moral, aesthetic, volitional qualities, attitude to work.

2. The lesson is conducted according to a strict system, depending on the form of teaching: a specific beginning, setting the goals and objectives of the lesson, explaining, reinforcing and repeating the musical material, homework. Types of musical activities should be interconnected and complementary.

3. The lesson is in accordance with the principles of teaching: it has an educational effect, is convenient for scientific understanding, allows the careful and conscious mastery of musical works, the formation of musical skills and abilities.

4. The content of the lesson is in accordance with the curriculum, which covers the links in the system of other lessons. It is important to keep in mind what has been studied in the past and what students need to learn after this lesson. The teacher also takes into account the specific situation in the school: equipment for music lessons, technical means, local styles and natural conditions, and so on.[5]

In addition to teaching, music lessons also include educational goals and objectives. They are determined by the content of the educational material, as well as by the general goals aimed at educating and developing the personality of schoolchildren. Educational tasks can be associated with the formation of moral, volitional, intellectual, emotional qualities of the person. The lesson is a certain stage in the continuous process of educating students.

In turn, the educational objectives of the lesson have a significant impact on the organization of music education and its methodology. For example, the formation of independence and cognitive activity as personality traits requires more attention in the classroom to creativity and tasks, different types of independent work.

The peculiarity of the music lesson is that in addition to the tasks of music education, the lesson also includes artistic and performance tasks. This is especially true of singing as a group that is an active form of music education at school. Singing as a group with very ancient and deep folk traditions develops not only musical abilities, but also the quality of character, worldview, artistic taste, aesthetic sense. Singing as a group combines different forms of work in the classroom: singing, music literacy, music comprehension, playing musical instruments, vocal creativity.

Modern music lessons are distinguished not only by the variety of forms of work and the richness of information, but also by the fact that they are technically armed. A tape recorder, music sets, music books, etc. visual aids, portraits of composers, projection devices, handouts, a set of musical instruments. In order for a music lesson to be as effective as possible, it must be carefully planned, consistently structured in terms of dramaturgy, and especially adequate with music.

\section{REFERENCES}

1. Gulomov S., Begalov B. Informatics and information technologies.- T .., Science, 2010. - P.45

2. Tokhtakhojaeva M. Theory and history of pedagogy // - T .: "Finance and Economics", 2008. - P.56

3. Sharipova G. Methodology. - T .: "Finance and Economics"2016. - P.32

4. Artikov T. Methods of teaching music. - T .: "Finance and Economics", 2010. - P.12 
CURRENT RESEARCH JOURNAL OF PEDAGOGICS 2(12): 119-123,

December 2021 DOI: https://doi.org/10.37547/pedagogics-crjp-02-12-24

ISSN 2767-3278

(C)2021 Master Journals

Crossref dof 81 Google

Accepted 18 ${ }^{\text {th }}$ December, $2021 \&$ Published 23 $3^{\text {th }}$ December, 2021

5. Kushinova R. Music teaching technologies and design - N.: 2019. - P.26 